\title{
The impact of acids approved for use in foods on the vitality of Haemonchus contortus and Strongyloides papillosus (Nematoda) larvae
}

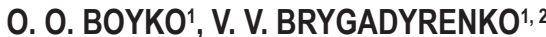

\begin{abstract}
${ }^{1}$ Dnipro State Agrarian and Economic University, S. Efremova St., 25, Dnipro, 49600, Ukraine, E-mail: boikoalexandra1982@gmail.com 1,2Oles Honchar Dnipro National University, Gagarin Ave. 72, Dnipro, 49010, Ukraine, E-mail: brigad@ua.fm
\end{abstract}

Article info

Received December 23, 2018

Accepted April 18, 2019

\section{Summary}

The laboratory experiment described in this article evaluated the death rate of larvae of Haemonchus contortus (Rudolphi, 1803) nematodes of the Strongylida order and Strongyloides papillosus (Wedl, 1856) of the Rhabditida order under the impact of different concentrations of 8 flavouring acids and source materials approved for use in and on foods and in medicine (formic, wine, benzoic, salicylic, stearic, kojic, aminoacetic, succinic acids). Minimum $\mathrm{LD}_{50}$ for third stage larvae of $\left(\mathrm{L}_{3}\right) \mathrm{S}$. papillosus was observed with salicylic and wine acids, for $\mathrm{L}_{3} \mathrm{H}$. contortus larvae - with formic acid. Minimum impact on all studied stages of development of nematodes was caused by stearic, kojic, aminoacetic and succinic acids: larvae did not die in the course of one day even at $1 \%$ concentration of these substances. The best parameters of $\mathrm{LD}_{50}$ were observed for benzoic and formic acid. Further experiments on flavouring acids and source materials approved for use in and on foods and in medicines, and also their compounds, will contribute to developing preparations with a stronger impact on nematode larvae - parasites of the digestive tract of vertebrate animals and humans.

Keywords: nematodes of ungulates; flavouring acids; death rate of larvae

\section{Introduction}

Achieving high quality livestock production requires following the rules of maintenance conditions. Important factors are the animals' diet and measures for preventing infections (Zazharska et al., 2018). One of the most common animal diseases around the world is considered to be helminthiasis. Annually it causes great losses in livestock production and great economic losses. An increasing amount of scientific research is being conducted on preventing and treating agricultural parasites. Farming uses synthetic anthelmintic preparations. Highly popular are broad spectrum anthelmintics: Albendazole, Fenbendazole, Ivermectin preparations (Belœil et al., 2003; Faye et al., 2003; Fthenakis et al., 2005; Veneziano et al., 2004; Charlier et al., 2007; Cringoli et al., 2008).

Also, research on the relative antiparasitic properties of plants is conducted all around the world (Rahmann \& Seip, 2006; Burke et al., 2009; Lu et al., 2010). Plant- based medical preparations against helminths show encouraging results. Rahmann and Seip (2006) suggest a list of plants with anthelmintic properties: black cumin, black walnut, boundary tree, common mugwort, common wormwood, crucifers, custard tree, eucalyptus, Eurasian wormwood, fargara, fennel, fern, fumitory garlic, Gambian mahagony, goosefoot, Indian lilac, kamala tree, neem tree, papaya, pinkroot, pumpkin, pyrethrum, sacred basil, southern wormwood, tansy, tarragon, wild carrot, and wild ginger.

A number of authors have studied the impact of sainfoins on the nematodes of animals: feeding sainfoins to goats reduces the number of eggs of Trichostrongylus sp. in the animals' feces (Paolini et al., 2005). Ferreira et al. (2011) described the impact of crude alcoholic extracts of Artemisia annua, A. absinthium, Asimi- 
na triloba, and Fumaria officinalis on trematodes in laboratory conditions in vitro.

Earlier, we tested against nematodes the following flavourings and source materials approved for use in and on foods: p-Anisaldehyde, Benzaldehyde, y-Undecalactone, Cinnamaldehyde, Ethyl acetate, Benzyl acetate, a-Terpineol, Benzyl alcohol, Citral, L-Linalool, $\beta$-lonone, Citronellol, Acetoin, D-Limonene (Boyko \& Brygadyrenko, 2019). The experiments showed that minimum $\mathrm{LD}_{50}$ for $\mathrm{L}_{3} \mathrm{~S}$. papillosus were achieved using Cinnamaldehyde, a-Terpineol and Benzyl alcohol, for $\mathrm{L}_{1-2}$ S. papillosus - using Benzyl alcohol, Cinnamaldehyde, L-Linalool and Benzyl acetate, for $\mathrm{L}_{3} \mathrm{H}$. contortus - using $\mathrm{y}$-Undecalactone and Cinnamaldehyde. Lowest indicators of $\mathrm{LD}_{50}(\mathrm{mg} / \mathrm{l})$ against Strongyloides ransomi Schwartz and Alicata, 1930 were observed using Benzaldehyde (Boyko \& Brygadyrenko, 2017b). When invasive eggs of $A$. suum, were exposed to Cinnamaldehyde, benzoic acid (E210, Codex Alimentarius) and methylparaben (E218, Codex Alimentarius) at $1 \%$ concentration, we determined the lowest parameters of LD50 for benzoic acid (Boyko \& Brygadyrenko, 2017a).

Strongyloidiasis and haemonchosis are some of the commonest helminthiases of Ruminantia. The development of Strongyloides spp. and Haemonchus spp. up to the invasive stage takes place in the external medium. The animals become infested with invasive larvae through intake of food and water. Nematodes of Strongyloides spp. have two generations. They consist of parasitic and free-living individuals, and therefore can breed both in the host's organism and in the external environment. At the same time, larvae of Strongyloides spp. can penetrate the host organism not only by the alimentary route, but also through the skin. These peculiarities of the life cycle of Strongyloides spp. can lead to intensive infection of animals. In cases of parasitisation of the gastrointestinal tract by Strongyloides spp., Haemonchus spp., and also other species of Strongylida, a decrease in weight and productivity parameters of animals, heightened sensitivity to other diseases, and at higher level of infestation - death of animals have been observed by numerous researchers (Kabasa et al., 1999; Vercruysse et al. 2001; Peter et al., 2015; Kobayashi \& Horii, 2008; Besier et al., 2016; Boyko et al., 2016; Flores-Pérez et al., 2019).

We found no information on the impact of the acids on helminths of the class Nematoda, which parasite in mammals. The research presented in this article is aimed at defining the vitality level of larvae of Haemonchus contortus (Rudolphi, 1803) and Strongyloides papillosus (Wedl, 1856) nematodes, parasites of ungulates, under the impact of flavouring acids and source materials approved for use in and on foods.

\section{Material and Methods}

The samples of ungulates' feces were obtained in Dnipropetrovsk Oblast, from the clinic of Dnipro National Agricultural-Economic University in 2017 . At a temperature regime of $+22 \ldots+24^{\circ} \mathrm{C}$ they were delivered to the laboratory of the Department of Parasitology and Veterinary-Sanitary Examination. The larvae of nematodes of goats' digestive tracts were cultivated in the conditions of thermostat during 8-days at the temperature of $+22 \ldots+24{ }^{\circ} \mathrm{C}$. The cultivation obtained third stage $\left(\mathrm{L}_{3}\right) \mathrm{H}$. contortus larvae and first, second and third stage $\left(L_{1}, L_{2}, L_{3}\right)$ S. papillosus larvae (Van Wyk et al. 2004; Van Wyk \& Mayhew 2013; Boyko et al., 2016). The larvae were obtained using the Baermann test (Zajac \& Conboy, 2011). $4 \mathrm{ml}$ of water with larvae was centrifuged for 4 minutes with 1,500 rotations per minute. The centrifuged sediment of liquid with nematode larvae $(0.1 \mathrm{ml})$ was put in plastic test tubes of $1.5 \mathrm{ml} \mathrm{ca}$ pacity. The solutions of acids were added, and the tubes were left in a thermostat for 24 hours at the temperature of $+22 \ldots+24{ }^{\circ} \mathrm{C}$.

The larvae were exposed to the impact of formic, wine, benzoic, salicylic, stearic, kojic, aminoacetic, succinic acids - flavourings and source materials approved for use in and on foods and in medicines. Three concentrations of the substances were used in eightfold replication for every variant of the experiment (Table 1). Benzoic acid is a substance of average toxicity. $\mathrm{LD}_{50}$ (median dose) of benzoic acid for laboratory animals (intravenous administration to rats) equals $1700 \mathrm{mg} / \mathrm{kg}$, for cats - $300 \mathrm{mg} / \mathrm{kg}$ (Bedford \& Clarke, 1972; Jakimowska, 1961). Formic acid has low toxicity. According to the classification of the European Union (Directive 67/548/EEC of 27 June 1967 on the approximation of laws, regulations and administrative provisions relating to the classification, packaging and labelling of dangerous substances), concentration of formic acid not higher than $10 \%$ has an irritating effect, over $10 \%$ - corrosive. $\mathrm{LD}_{50}$ (median dose) of formic acid for laboratory animals equals $700,1100,4000 \mathrm{mg} / \mathrm{kg}$ for mice, rats and dogs respectively (oral) (Von Oettingen, 1960, Montgomery, 2000). Wine acid (Tartaric acid) is used in the food industry as a E334 additive (Codex Alimentarius). $\mathrm{LD}_{50}$ is about $5.3 \mathrm{~g} / \mathrm{kg}$ for rabbits, and $4.4 \mathrm{~g} / \mathrm{kg}$ for mice (Maga, Tu, 1995). Salicylic acid is toxic for humans only in high doses. $\mathrm{LD}_{50}$ (median dose) of salicylic acid for laboratory animals (mice, intravenous) is $184 \mathrm{mg} / \mathrm{kg}$ (Ozawa et al., 1971). Stearic acid is broadly used in cosmetics. $\mathrm{LD}_{50}$ (median dose) of stearic acid for laboratory animals is $21.5 \mathrm{mg} / \mathrm{kg}$ (rats, intravenous), $23 \mathrm{mg} / \mathrm{kg}$ (mice, intravenous) (Oro \& Wretlind, 1961). Kojic acid is broadly used in the food industry, cosmetology, and also medicine. Aminoacetic acid is also used widely. It is used in the food industry (E640), for preparing pharmaceutical preparations, fodders for animals. $\mathrm{LD}_{50}$ (median dose) of aminoacetic acid is 7930, $\mathrm{mg} / \mathrm{kg}$ (rats, oral) (Wypych, 2016). As a food additive and dietary supplement, succinic acid is generally recognized as safe by the U.S. Food and Drug Administration. This acid is used in the food industry as a E363 additive. Also it is used for obtaining medical preparations. $\mathrm{LD}_{50}$ is $2702 \mathrm{mg} / \mathrm{kg}$ for laboratory animals (mice, intraperitoneal) (Domingo et al., 1990).

The statistical analysis of the results was performed through a set of Statistica 8.0 (StatSoft Inc., USA).On the figures is shown the median, $25 \%$ and $75 \%$ quartiles, minimum and maximum values. $\mathrm{LD}_{50}$ is expressed as a \%: average $(\mathrm{x}) \pm$ standard deviation (SD). 
Table 1. Usage and properties of acids used for defining the vitality level of $H$. contortus and S. papillosus larvae

\begin{tabular}{|c|c|c|c|}
\hline $\begin{array}{l}\text { The name } \\
\text { of substance }\end{array}$ & $\begin{array}{l}\text { Chemical } \\
\text { formula }\end{array}$ & Structural formula & Usage \\
\hline $\begin{array}{l}\text { benzoic acid } \\
\qquad\left(E_{210}\right)\end{array}$ & $\mathrm{C}_{7} \mathrm{H}_{6} \mathrm{O}_{2}$ & & $\begin{array}{l}\text { used for preserving food products; used in medicine } \\
\text { for treating skin diseases, as dermatic antiseptic and } \\
\text { fungicidal preparation }\end{array}$ \\
\hline $\begin{array}{l}\text { formic acid } \\
\qquad\left(E_{236}\right)\end{array}$ & $\mathrm{CH}_{2} \mathrm{O}_{2}$ & & $\begin{array}{l}\text { as a preserving and antibacterial agent in preparation } \\
\text { of fodder; against parasites of bees }\end{array}$ \\
\hline $\begin{array}{l}\text { wine acid } \\
\qquad\left(\mathrm{E}_{334}\right)\end{array}$ & $\mathrm{C}_{4} \mathrm{H}_{6} \mathrm{O}_{6}$ & & used in food production and medicine \\
\hline salicylic acid & $\mathrm{C}_{7} \mathrm{H}_{6} \mathrm{O}_{3}$ & & $\begin{array}{l}\text { has slight antiseptic, irritating and keratolytic } \\
\text { properties, used in medicine in the content of } \\
\text { unguents and solutions for treating skin diseases }\end{array}$ \\
\hline stearic acid & $\mathrm{C}_{18} \mathrm{H}_{36} \mathrm{O}_{2}$ & & $\begin{array}{l}\text { is one of the main components of soap, is included in } \\
\text { many cosmetic preparations }\end{array}$ \\
\hline kojic acid & $\mathrm{C}_{6} \mathrm{H}_{6} \mathrm{O}_{4}$ & & $\begin{array}{l}\text { is a reaction inhibitor of formation of melanin, and } \\
\text { also is used in food production and cosmetology for } \\
\text { preserving or changing colour of substances, is a } \\
\text { component of antibiotics, insecticides and pesticides; } \\
\text { has an anti-inflammatory, bactericidal, insecticidal } \\
\text { and fungicidal effect }\end{array}$ \\
\hline $\begin{array}{l}\text { aminoacetic acid } \\
\left(\mathrm{E}_{640}\right)\end{array}$ & $\mathrm{C}_{2} \mathrm{H}_{5} \mathrm{NO}_{2}$ & & $\begin{array}{l}\text { for preparing buffer solutions, synthesis of peptides, } \\
\text { hippuric and amino-hippuric acids, as a complexing } \\
\text { reagent; used for obtaining fertilizers, nitrates of } \\
\text { cellulose, colourings, sulfur acid, etc.; used in the } \\
\text { food industry }\end{array}$ \\
\hline $\begin{array}{l}\text { succinic acid } \\
\qquad\left(\mathrm{E}_{363}\right)\end{array}$ & $\mathrm{C}_{4} \mathrm{H}_{6} \mathrm{O}_{4}$ & & $\begin{array}{l}\text { used for obtaining medical preparations, in particular, } \\
\text { Chinotilinum; also used in the food industry }\end{array}$ \\
\hline
\end{tabular}

\section{Ethical Approval and/or Informed Consent}

This work does not involve human or experimentation with animals.

\section{Results}

The best results were shown by benzoic and formic acids. A total of $100 \%$ of $L_{3} H$. contortus and $L_{1}, L_{2}, L_{3} S$. papillosus larvae died at $1 \%$ concentration of both solutions (Fig. 1 a, b). But about $100 \%$ of $L_{3} S$. papillosus and $L_{3} H$. contortus $L_{1}, L_{2} S$ survived in the next $(0.01 \%)$ concentration of benzoic acid. $L_{1}, L_{2} S$. papillosus were less resistant to $0.01 \%$ concentration of benzoic acid we observed around $70 \%$ viable individuals at this concentration.
Under the impact of $0.01 \%$ concentration of formic acid, $100 \%$ of invasive larvae of $\left(\mathrm{L}_{3} \mathrm{H}\right.$. contortus and $\mathrm{L}_{3} \mathrm{~S}$. papillosus) nematodes and $50 \%$ of $L_{1}, L_{2} S$. papillosus survived. Lower concentrations of these acids showed no positive effect, vitality of larvae of all stages remained at $100 \%$.

Stearic acid was not effective against nematodes S. papillosus and H. contortus. Under different concentrations of this acid, $100 \%$ of $\mathrm{L}_{3}$ survived. Only $\mathrm{L}_{2} \mathrm{~S}$. Papillosus were affected by $1 \%$ concentration of stearic acid: only $10 \%$ of individuals remained alive. The impact of the next concentration $(0.01 \%)$ provided no positive effect: $80 \%$ of $L_{1}, L_{2}$ S. papillosus (Fig. $1 \mathrm{c}$ ) survived.

The study of the impact of succinic (Fig. $1 \mathrm{~d}$ ) and aminoacetic acids (Fig. 2 a) also showed a negative anthelmintic effect. About $80 \%$ of $L_{3}$ S. papillosus and $100 \% L_{3} H$. contortus remained alive 

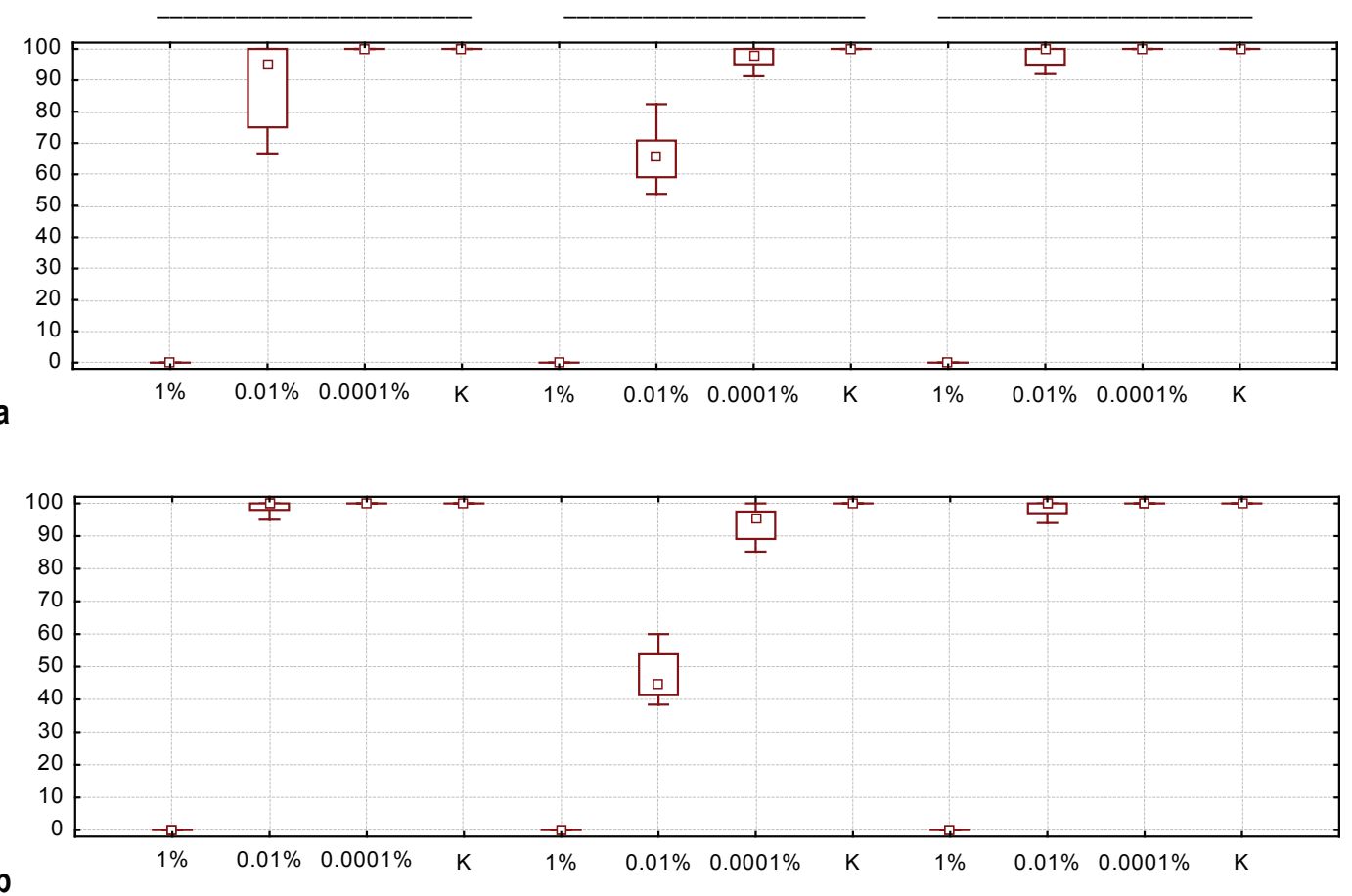

b

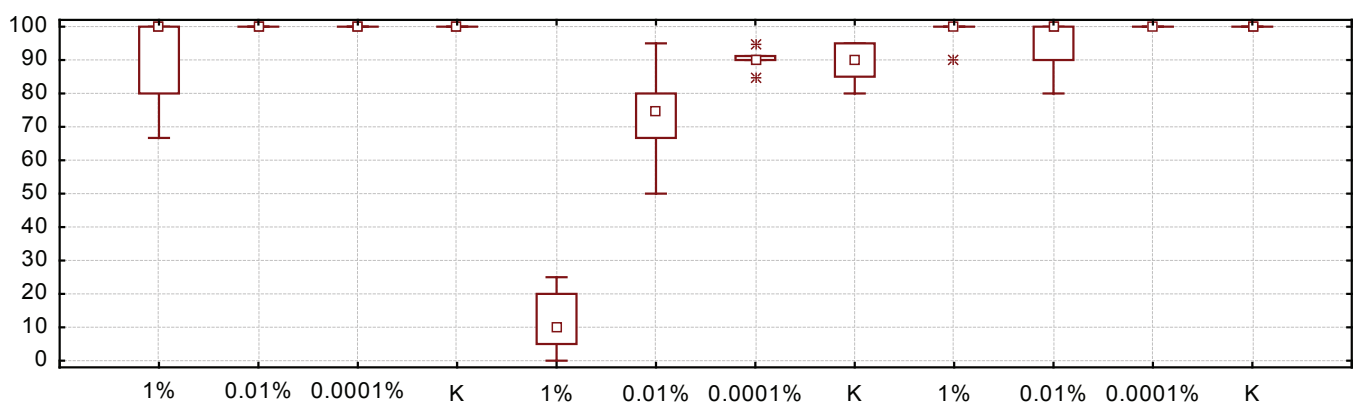

C

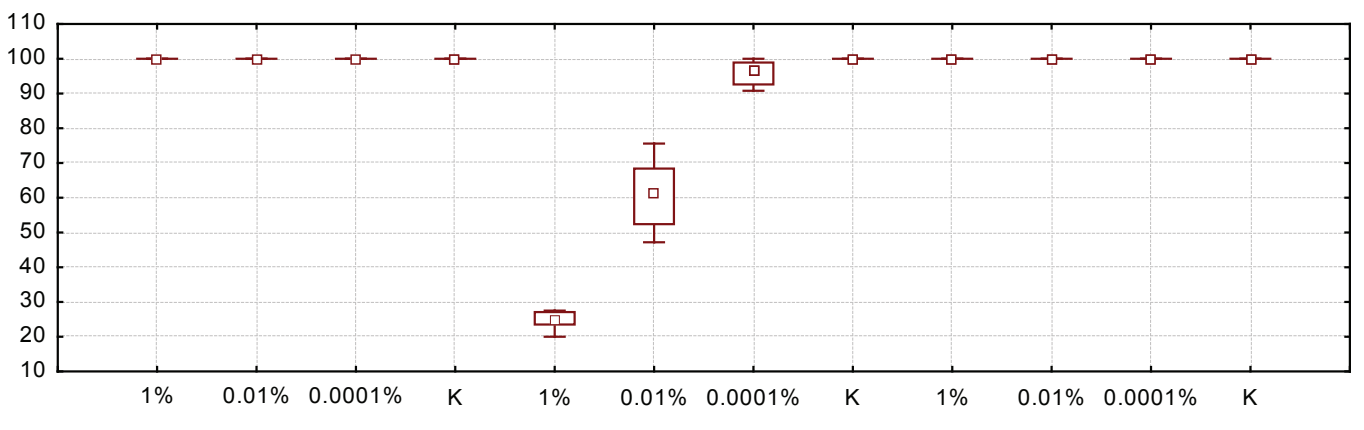

Fig. 1. The impact of benzoic (a), formic (b), stearic (c) and succinic (d) acid on vitality of larvae of nematodes of ruminants: the ordinate axis indicates the percentage of living nematode larvae in the course of the 24-hour experiment; the abscissa axis indicates the concentration of the solution's active substance (\%); (K) control, where the concentration of the active substance is $0 \% ;\left(\mathrm{L}_{3}\right)$ invasive larvae of $S$. papillosus or $\mathrm{H}$. contortus; $\left(\mathrm{L}_{1}, \mathrm{~L}_{2}\right)$ non-invasive larvae of $\mathrm{S}$. papillosus; the small square in the centre corresponds to the median, the lower and upper edge of the large rectangle corresponds to first and third quartiles, respectively, the vertical segments, directed upward and downward from the rectangles, correspond to minimum and maximum values $(n=8)$ 


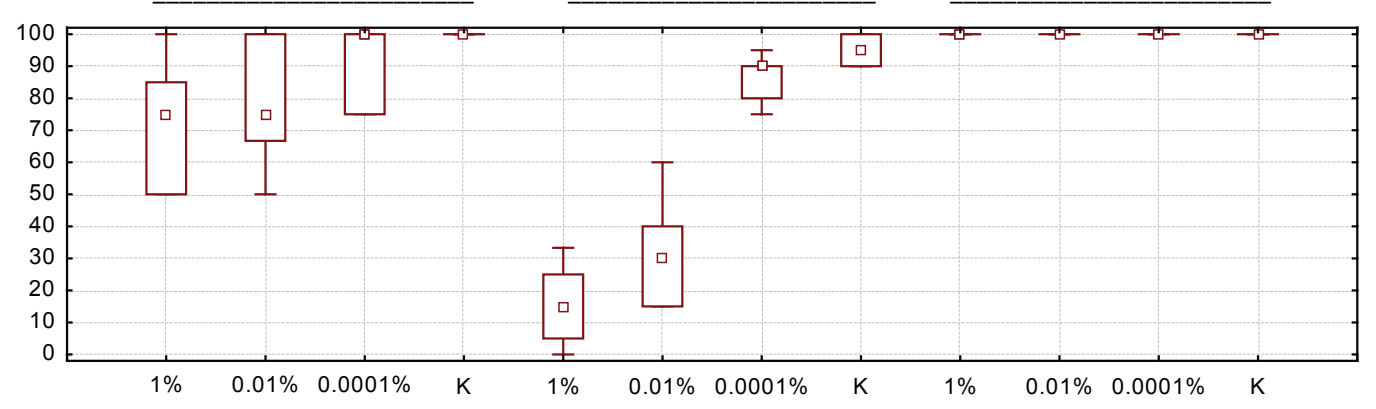

a

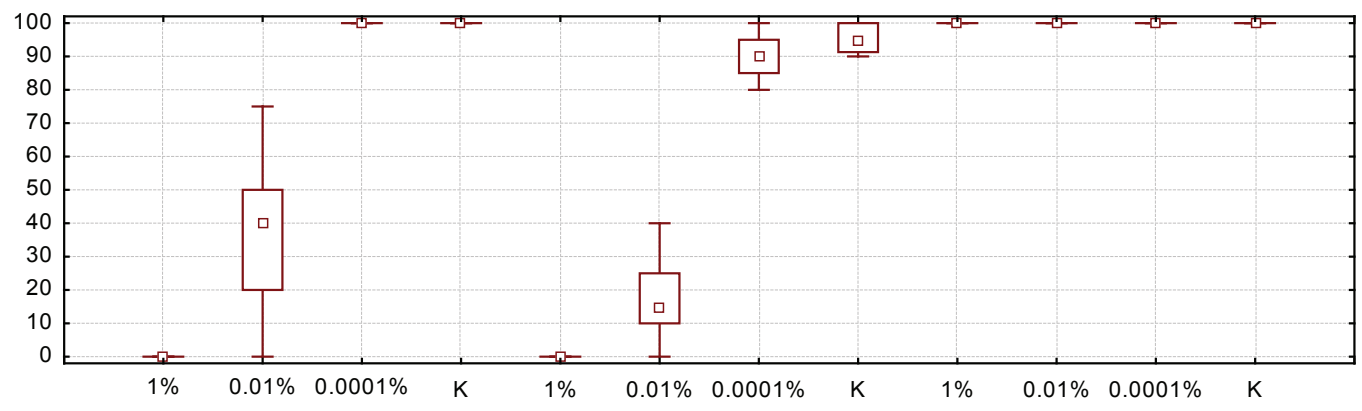

b

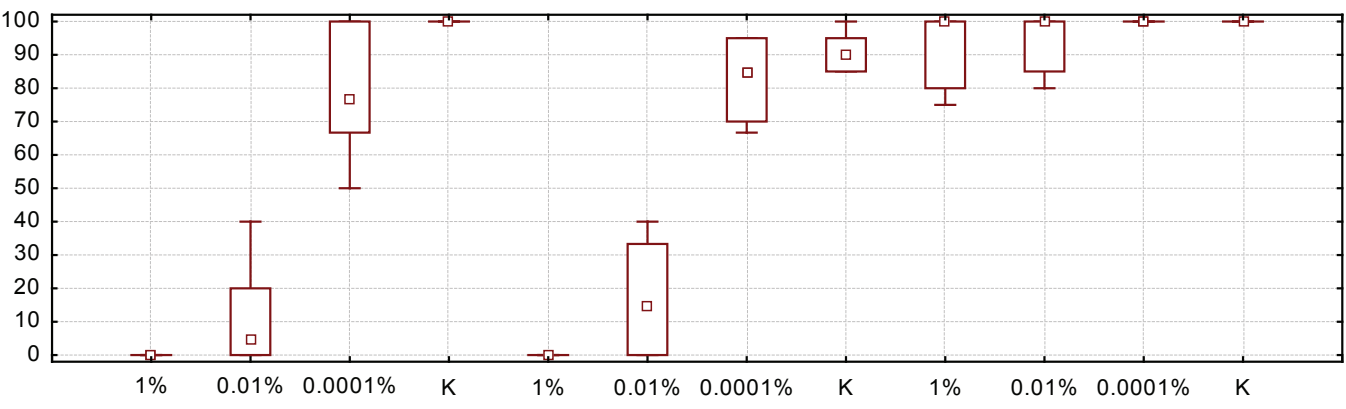

C

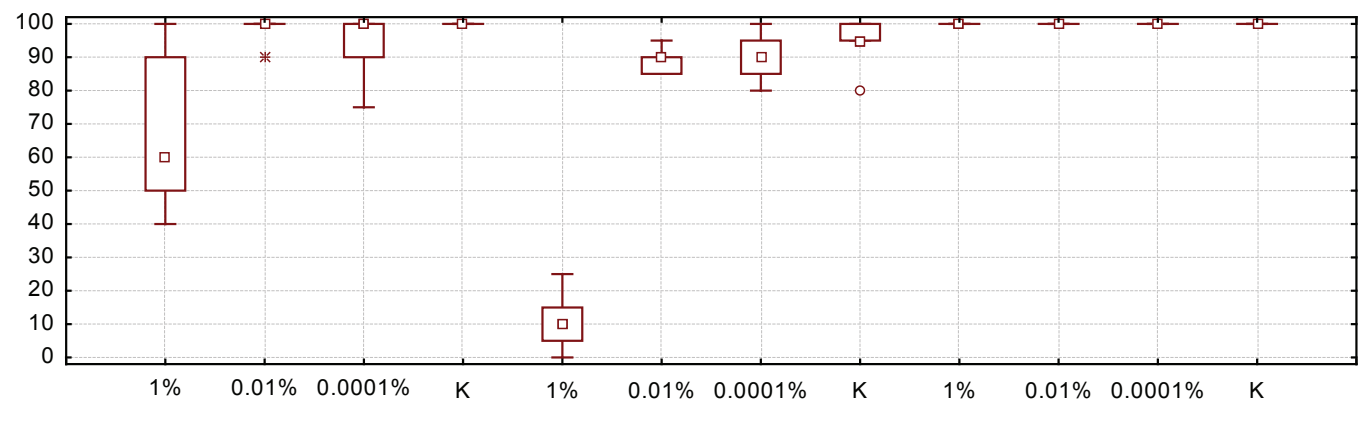

Fig. 2. The effect of aminoacetic (a), wine (b), salicylic (c) and kojic (d) acid on vitality of larvae of nematodes of ruminants': explanations see in Fig. 1. 
Table 2. $\mathrm{LD}_{50}(\%, \mathrm{x} \pm \mathrm{SD})$ for $\mathrm{S}$. papillosus and $\mathrm{H}$. contortus larvae in laboratory experiment during 24 hours; $(-)$ the experiment did not achieve death of $50 \%$ of the larvae (over $1 \%$ concentration is needed)

\begin{tabular}{lccc}
\hline \multicolumn{1}{c}{ Substance } & S. papillosus, $\mathrm{L}_{3}$ & S. papillosus, $\mathrm{L}_{1}+\mathrm{L}_{2}$ & H. contortus, $\mathrm{L}_{3}$ \\
\hline benzoic acid & $0.18 \pm 0.14$ & $0.07 \pm 0.04$ & $0.52 \pm 0.18$ \\
formic acid & $0.47 \pm 0.29$ & $0.008 \pm 0.007$ & $0.41 \pm 0.32$ \\
wine acid & $0.008 \pm 0.005$ & $0.006 \pm 0.004$ & - \\
salicylic acid & $0.0010 \pm 0.0006$ & $0.0009 \pm 0.0006$ & - \\
stearic acid & - & $0.09 \pm 0.03$ & - \\
kojic acid & - & $0.08 \pm 0.03$ & - \\
aminoacetic acid & - & $0.006 \pm 0.004$ & - \\
succinic acid & - & $0.08 \pm 0.03$ & - \\
\hline
\end{tabular}

under the impact of aminoacetic acid. $100 \%$ of all invasive $L_{3} S$. papillosus and $\mathrm{L}_{3} \mathrm{H}$. contortus) survived in $1 \%$ solution of succinic acid. $L_{1}, L_{2} S$. papillosus were less resistant to the acids. Only $15 \%$ and $25 \%$ of the larvae withstood $1 \%$ solution of aminoacetic and succinic acids respectively. The next concentration of aminoacetic acid $(0.01 \%)$ also caused positive results only with $L_{1}, L_{2}$ S. papillosus: about $70 \%$ of the larvae died. In $0.01 \%$ solution of succinic acid, the larvae were more resistant: around $60 \%$ survived. Smaller concentrations provided no positive effect against larvae of $L_{1}, L_{2} L_{3}$ nematodes of the studied species.

Wine acid showed a less significant nematocidal effect. None of the $L_{3} H$. contortus died even in $1 \%$ concentration of this substance. By contrast, the larvae of $S$. papillosus of all stages of development died at this concentration. But the next concentration of the wine acid solution $(0.01 \%)$ caused mortality of only $40 \%$ of $L_{3}$ S. papillosus and $15 \%$ of $L_{3}$ S. papillosus. $100 \% L_{3}$ of both studied species of nematodes survived at $0.0001 \%$ concentration of this acid (Fig. 2 b).

Exposure to $1 \%$ solution of salicylic acid caused death of only S. papillosus larvae. No more than $20 \%$ of the larvae were able to withstand $0.01 \%$ solution. Exposing S. papillosus larvae to $0.0001 \%$ concentration of salicylic acid did not lead to positive results: more than $70 \%$ of the larvae remained alive. $\mathrm{L}_{3} \mathrm{H}$. contortus larvae were found to be the most resistant to different concentrations of this acid (Fig. $2 \mathrm{c}$ ).

Similar results were obtained after using kojic acid. Over $60 \%$ of $\mathrm{L}_{3} \mathrm{~S}$. papillosus and $\mathrm{L}_{3} \mathrm{H}$. contortus survived in $1 \%$ solution of this acid. Non-invasive larvae also appeared to be less resistant to the acid: vitality of $L_{1}, L_{2}$ S. papillosus larvae was only $10 \%$ at such concentration. Over $90 \%$ of the larvae of the studied nematode species survived at $0.01 \%$ concentration of kojic acid (Fig. 2 d). Thus, the best $\mathrm{LD}_{50}$ indicators were observed for benzoic and formic acids. These acids caused death of all studied species of nematode larvae. Stearic, kojic, aminoacetic and succinic acids did not demonstrate a significant impact on the nematode larvae. They increased mortality of only $L_{1}, L_{2} S$. papillosus (Table 2 ).

\section{Discussion}

Therefore, flavourings and source materials approved for use in and on foods and acids used in medicine and cosmetology are capable of having a significant effect on vitality of larvae of nematodes of ruminants (S. papillosus, $H$. contortus). Currently, scientists are closely studying natural factors which are unfavourable for parasites of agricultural animals and plants. The question of using anthelmintic substances of non-synthetic origin against agricultural pests is becoming increasingly relevant. The issues we are interested in, the impacts of flavouring acids and source materials approved for use in and on foods and acids used in medicine and cosmetology, are being reported in the scientific literature. Positive results in using acids against nematodes were also achieved by Browning et al. (2004). They described the nematocidal properties of butyric acid, which is obtained through fermentation of organic substances by anaerobic soil bacteria. A 2-day incubation in sand amended with $0.88 \mathrm{mg} / \mathrm{g}$ butyric acid reduced plant parasitic and fungivorous nematodes by $84-100 \%$ as compared to untreated controls. The species compound of nematodes is highly significant. Significant decrease in the number of some species requires using $0.88 \mathrm{mg}$ butyric acid / $\mathrm{g}$ of sand, others (Steinernema) require 8.8 $\mathrm{mg}$ butyric acid / $\mathrm{g}$ of sand in order to effect a significant decline (85\%). Therefore, when formic and benzoic acids are used, much lower concentrations are needed for eliminating nematode larvae $(0.01 \mathrm{~g} / \mathrm{ml})$ than for butyric acid. Using the gaseous phase of butyric acid against plant nematodes in a 7-day incubation period showed similar results. The vapour from a $0.1 \mathrm{M}$ solution reduced plant-parasitic and fungivorous nematodes by $89-96 \%$ while the vapour from a $1 \mathrm{M}$ solution of butyric acid reduced entomogenous nematodes by $94-99 \%$.

Browning et al. (2006) have also studied in laboratory conditions the nematocidal properties of butyric acid on fungal and nematode endoparasites of strawberries. Drenching strawberry plants infested with Pratylenchus penetrans with butyric acid (0.1 and $1 \mathrm{M}$ ) reduced nematode densities by $98-100 \%$. The results of their 
research prove the hypothesis that butyric acid is an alternative to synthetic substances.

Sahebani et al. (2011) in their research mentioned the impact of $\beta$-aminobutyric acid on nematodes of gherkin roots (Meloidogyne javanica). They presume that this acid is capable of improving protection reactions in gherkin roots.

Sources from the literature contain a large amount of information on the impact of the studied substances on nematode parasites of mammals, insects, and plants. Moslemi et al. (2016) observed salicylic acid to demonstrate inhibitory effects against Meloidogyne javanica, a nematode of plants, by inhibiting its reproduction in tomato plants. Nematocidal activity of kojic acid was determined by Kim et al. (2016) in the course of a study of its impact on Meloidogyne incognita, a parasite of agricultural plants. Our results were negative regarding the mortality of nematode larvae exposed to kojic acid. However, in their experiments, Kim et al. (2016) determined a much higher concentration of kojic acid for eliminating nematodes compared to the concentration we used in our experiment. Accordingly, the researchers observed death of $60 \%$ of nematodes at concentration of $333.3 \mathrm{mg} / \mathrm{ml}$. By contrast, in our experiments, concentrations higher than $10 \mathrm{~g} / \mathrm{l}$ were not used. However, even such a concentration led to similar results for its effect on non-invasive larvae (around $40 \%$ of larvae died). One of the most widely used substances against parasites currently is formic acid. We also observed positive results against larvae of nematodes of animals: even $1 \%$ solution caused death of $L_{1}$, $L_{2} L_{3}$ of all studied species of nematodes. Although we found no data in the literature on the relative impact of this acid on vitality of mature nematodes, their larvae and eggs, it is often used against Acari parasites of bees (Underwood \& Currie, 2003; Underwood \& Currie, 2007). According to Underwood et al. (2003), even 0.08 and $0.16 \mathrm{mg} / \mathrm{l}$ doses of formic acid is efficient against the Acari Varroa destructor at a temperature of over $5^{\circ} \mathrm{C}$. Nonetheless, the highest medical efficiency was observed for a dose of $0.16 \mathrm{mg} / \mathrm{l}$ at the temperature of $35^{\circ} \mathrm{C}$. In treatment of coccidiosis, one may use compounds including formic, acetic, propionic, succinic, glycolic, lactic, malic, tartaric, citric, ascorbic, maleic, pyruvic and other acids (Muzi \& Rahman, 2005). We obtained slightly different results for succinic and tartaric acids. Though $L_{1}, L_{2} S$. papillosus were also exposed to their impact, $L_{3} S$. papillosus and $L_{3} H$. contortus were resistant to succinic acid, and $\mathrm{L}_{3} H$. contortus to both succinic and tartaric acids.

Benzoic acid - carboxylic acid of aromatic compound (E210 Codex Alimentarius) is used as a powerful antiseptic and fungicide. It is included in preservatives - food additives, such as E211 - Sodium Benzoate, E212 - Potassium Benzoate, E213 - Calcium Dibenzoate and others (Beerse et al., 2001; Amborabe et al., 2002; Joshi et al., 2008). The results of our study also prove the nematocidal activity of this acid in relation to larvae of nematodes of animals. A $1 \%$ solution can cause death of larvae of $S$. papillosus and $H$. contortus nematodes.

\section{Conclusion}

Using food additives, including acids against parasites of animals and humans is one of the new directions in veterinary medicine and biology. Periodic addition to fodder of these substances with nematocidal properties can manage the intensity of helminth infection. Therefore, it is possible for farmers to maintain dairy and meat products at a high level without using anthelmintic preparations of synthetic origin, farmers can. Further experiments can lead to development of preparations containing formic and benzoic acids.

\section{References}

Amborabe, B-E., Fleurat-Lessard, P., Chollet, J.F., Roblin, G. (2002): Antifungal effects of salicylic acid and other benzoic acid derivatives towards Eutypa lata: Structure - activity relationship. Plant. Physiol. Biochem., 40: 1051 - 1060. DOI: https://doi. org/10.1016/S0981-9428(02)01470-5

Bedford, P., Clarke, E. (1972): Experimental benzoic acid poisoning in the cat. Vet. Rec., 90(3): 53 - 58. DOI:10.1136/vr.90.3.53

Beerse, P.W., Biedermann, K.A., Page, S.H., Mobley, M.J., Morgan, J.M. (2001): Antimicrobial compositions comprising a benzoic acid analog and a metal salt. U.S. Patent No. 6294186. Lybertyville, IL, USA.

Beloeil, P.A., Chauvin, C., Fablet, C., Jolly, J.P., Eveno, E., Madec, F., Reperant, J.M. (2003): Helminth control practices and infections in growing pigs in France. Livest. Prod. Sci., 81: 99 - 104. DOI:10.1016/S0301-6226(02)00192-6

Besier, R.B., Kahn, L. P., Sargison, N.D., Van Wyk, J.A. (2016): The pathophysiology, ecology and epidemiology of Haemonchus contortus infection in small ruminants. Adv. Parasitol., 93: 95 - 143. DOI: 10.1016/bs.apar.2016.02.022

Boyko, A.A., Brygadyrenko, V.V. (2017a): Changes in the viability of the eggs of Ascaris suum under the influence of flavourings and source materials approved for use in and on foods. Biosyst. Divers., 25(2): 162 - 166. DOI: 10.15421/011724

Boyko, A.A., Brygadyrenko, V.V. (2017b): Changes in the viability of Strongyloides ransomi larvae (Nematoda, Rhabditida) under the influence of synthetic flavourings. Regul. Mech. Biosyst., 8(1): 36 40. DOI:10.15421/021707

Boyko, O.O., Brygadyrenko, V.V. (2019): The viability of Haemonchus contortus (Nematoda, Strongylida) and Strongyloides papillosus (Nematoda, Rhabditida) larvae exposed to concentrations of flavourings and source materials approved for use in and on foods. Vestn. Zool., 53: in press.

Boyko, O.O., Duda, Y.V., Pakhomov, O.Y., Brygadyrenko, V.V. (2016): Comparative analysis of different methods of staining the larvae Haemonchus contortus, Mullerius sp. (Nematoda, Strongylida) and Strongyloides papillosus (Nematoda, Rhabditida). Folia Oecol., 43(2), $129-137$ 
Boyko, O.O., ZaZHARSKa, N.M., BrygadYrenko, V.V. (2016): The influence of the extent of infestation by helminths upon changes in body weight of sheep in Ukraine. Visn. Dnipropetr. Univ. Ser. Biol. Ecol., 24(1): 3 - 7. DOI: 10.15421/011601

Browning, M., Dawson, C., Alm, S.R., Gorrës, J.H., Amador, J.A. (2004): Differential effects of butyric acid on nematodes from four trophic groups. Appl. Soil. Ecol., 27: 47 - 54. DOI: 10.1016/j.apsoil.2004.03.005

Browning, M., Wallace, D.B., Dawson, C., Alm, S.R., Amador, J.A. (2006): Potential of butyric acid for control of soil-borne fungal pathogens and nematodes affecting strawberries. Soil. Biol. Biochem., 38: 401 - 404. DOI: 10.1016/j.soilbio.2005.05.020

BuRke, J.M., Wells, A., Casey, P., Kaplan, R.M. (2009): Herbal dewormer fails to control gastrointestinal nematodes in goats. Vet. Parasitol., 160: 168 - 170. DOI: 10.1016/j.vetpar.2008.10.080

Charlier, J., Duchateau, L., Claerebout, E., Willams, D., VerCRUYSSE, J. (2007): Associations between anti-Fasciola hepatica antibody levels in bulk-tank milk samples and production parameters in dairy herds. Prev. Vet. Med., 78: 57 - 66. DOI: 10.1016/j. prevetmed.2006.09.010

Cringoli, G., Veneziano, V., Jackson, F., Vercruysse, J., Greer, A.W., Fedele, V., MezzIno, L., RinaldI, L. (2008): Effects of strategic anthelmintic treatments on the milk production of dairy sheep naturally infected by gastrointestinal strongyles. Vet. Parasitol., 156: 340 - 345. DOI: 10.1016/j.vetpar.2008.06.015

Domingo, J.L., Gomez, M., Llobet, J.M., Corbella, J. (1990): Chelating agents in the treatment of acute vanadyl sulphate intoxication in mice. Toxicology, 62(2): 203 - 211. DOI:10.1016/0300483x(90)90110-3

Faye, D., Leak, S., Nouala, S., Fall, A., Losson, B., Geerts, S. (2003): Effects of gastrointestinal helminth infections and plane of nutrition on the health and productivity of F1 (West African Dwarf $\times$ Sahelian) goat crosses in The Gambia. Small. Rumin. Res., 50: 153 - 161. DOI: 10.1016/S0921-4488(03)00108-1

FerReIRA, J.F.S., PeAden, P., KeISER, J. (2011): In vitro trematocidal effects of crude alcoholic extracts of Artemisia annua, A. absinthium, Asimina triloba, and Fumaria officinalis. Parasitol. Res., 109: 1585 - 1592. DOI: 10.1007/s00436-011-2418-0

Flores-Pérez, I., Hallal-Calleros, C., Cervantes-Pacheco, B.J., Alba-Hurtado, F., Orihuela, A., Castro-del-Campo, N., Acevedo-Ramirez, P., Ortiz-López, B., Jimenez-Leyva, D., Barajas-Cruz, R. (2019): Behavioural and productive response to experimental infection with stage 3 larvae of Haemonchus contortus in feedlot bull-calves. Exp. Parasitol., 197: 1 - 8. DOI: 10.1016/j.exppara.2018.12.005

Fthenakis, G.C., Papadopoulos, E., Himonas, C. (2005): Effects of three anthelmintic regimes on milk yield of ewes and growth of lambs. Vet. Med., 52: 78 - 82. DOI: 10.1111/j.14390442.2004.00687.x

JAKIMOWSKA, K. (1961): Pharmacological properties of certain aromatic boron compounds. Acta Physiol. Polonica, 12: 173 - 182 (In Polish)
JoSH, S.D., Vagdevi, H.M., Vaidya, V.P., Gadaginamath, G.S. (2008): Synthesis of new 4-pyrrol-1-yl benzoic acid hydrazide analogs and some derived oxadiazole, triazole and pyrrole ring systems: A novel class of potential antibacterial and antitubercular agents. Eur. J. Med. Chem., 43: 1989 - 1996. DOI: 10.1016/j.ejmech.2007.11.016 Kabasa, J.D, Opuda-Asibo, J., Meulen, U. (1999): The effect of oral administration of polyethylene glycol on faecal helminth egg counts in pregnant goats grazed on browse containing condensed tannins. Trop. Anim. Hlth Prod., 32(2): 73 - 86.

KoBAYASH, I., HoRII, Y. (2008): Gastrointestinal motor disturbance in rabbits experimentally infected with Strongyloides papillosus. Vet. Parasitol., 158: 67 - 72. DOI: 10.1016/j.vetpar.2008.08.017

KIm, T.Y., Jang, J.Y., Jeon, S.J., LeE, H.W., BaE, C.-H., YeO, J.H., LeE, H.B., KIm, I.S., Park, H.W., KIm, J.-C. (2016): Nematicidal activity of kojic acid produced by Aspergillus oryzae against Meloidogyne incognita. J. Microbiol. Biotechnol., 26(8): 1383 - 1391. DOI: 10.4014/jmb.1603.03040

Lu, C.D., GanGYI, X., KaWASC, J.R. (2010): Organic goat production, processing and marketing: Opportunities, challenges and outlook. Small Rumin. Res., 89: 102 - 109. DOI: 10.1016/j.smallrumres.2009.12.032

MagA, J.A., Tu, A.T. (1995): Food additive toxicology. CRC Press, Boca Raton. Pp. 137 - 138

Montgomery, J. (2000): Groundwater chemicals desk reference. 3rd edition. Imprint CRC Press, Boca Raton. DOI:10.1201/9781420032765

Moslemi, F., Fatemy, S., Bernard, F. (2016): Inhibitory effects of salicylic acid on Meloidogyne javanica reproduction in tomato plants. Span. J. Agric. Res., 14(1): e1001. DOl:10.5424/sjar/2016141-8706 MuZI, S., RAHMAN, S.H.A. (2005): Urea and thiourea compounds useful for treatment of coccidiosis. U.S. Patent No. 6,875,764 B1. ORO, L., WRETLIND, A. (1961): Pharmacological effects of fatty acids, triolein and cottonseed oil. Acta Pharmacol. Toxicol., 18: 141 - 152 Ozawa, H., Seto, S., Mural, S., \& Olzumi, Y. (1971): Pharmacological studies of troponoids. I. Hypothermic, analgesic and anti-inflammatory actions of troponoids. Yakugaku Zasshi, 91(5): 550 - 559 (In Japanese).

Paolini, V., De La Farge, F., Prevot, F., Dorchies, P., Hoste, H. (2005): Effects of the repeated distribution of sainfoin hay on the resistance and the resilence of goats naturally infected with gastrointestinal nematodes. Vet. Parasitol., 127: 277 - 283. DOI: 10.1016/j.vetpar.2004.10.015

Peter, G.Sh., Gitau, G.K., Mulel, Ch.M., Vanleeuwen, J., Richards, Sh., Wichtel, J., Uehlinger, F., Mainga, O. (2015): Prevalence of Cryptosporidia, Eimeria, Giardia, and Strongyloides in preweaned calves on smallholder dairy farms in Mukurwe-ini district, Kenya. Vet. World. Sep., 8(9): 1118 - 1125. DOI: 10.14202/vetworld.2015.1118-1125

RahmanN, G., SeIP, H. (2006): Alternative strategies to prevent and control endoparasite diseases in organic sheep and goat farming systems. Ressortforschung für den Ökologischen Landbau, $49-90$ 
Sahebani, N., Hadavi, N.S., Zade, F.O. (2011): The effects of $\beta$-amino-butyric acid on resistance of cucumber against root-knot nematode, Meloidogyne javanica. Acta Physiol. Plant., 33: 443. DOI: 10.1007/s11738-010-0564-0

UnderWood, R.M., CurRIE, R.W. (2003): The effects of temperature and dose of formic acid on treatment efficacy against Varroa destructor (Acari: Varroidae), a parasite of Apis mellifera (Hymenoptera: Apidae). Exp. Appl. Acarol., 29: 303. DOl: 10.1023/A:1025892906393

UnDERWOOD, R.M., CURRIE, R.W. (2007): Effects of release pattern and room ventilation on survival of Varroa mites and queens during indoor winter fumigation of honey bee colonies with formic acid. Can. Entomol., 139: 881 - 893. DOI: 10.4039/n06-085

Veneziano, V., Rubino, R., Fedele, V., Rinaldi, L., Santaniello, M., Schioppi, M., Cascone, C., PIzZILlo, M., CRIngoli, G. (2004): The effects of five anthelmintic treatment regimes on milk production in goats naturally infected by gastrointestinal nematodes. S. Afr. J. Anim. Sci., 34: $238-240$

Van Wyk, J., Cabaret, J., Michael, L.M. (2004): Morphological identification of nematode larvae of small ruminants and cattle simplified. Vet. Parasitol., 119(4): 277 - 306. DOI: 10.1016/j.vetpar.2003.11.012

Van WYK, J.A., MAYheW, E. (2013): Morphological identification of parasitic nematode infective larvae of small ruminants and cattle: A practical lab guide. Onderstepoort J. Vet. Res., 80: 1 - 14. DOI: 10.4102/ojvr.v80i1.539

VerCRUYSSE, J., ClaEREBOUt, E. (2001): Treatment vs non-treatment of helminth infections in cattle: Defining the threshold. Vet. Parasitol., 98 (1-3): 195 - 214. DOI: 10.1016/s0304-4017(01)00431-9 Von OetTingen, W.F. (1960): The aliphatic acids and their esters: Toxicity and potential dangers. The saturated monobasic aliphatic acids and their esters. Arch. Indmt. Health, 21(1): $28-65$

WYPYCH, G. (Ed) (2016): Chemical origin of nucleating agents. Handbook of Nucleating Agents. ChemTec Publishing, Toronto. Pp. 5-31. DOI:10.1016/b978-1-895198-93-5.50004-6

ZAJAC, A.M., ConBoy, G.A. (Eds) (2011): Veterinary clinical parasitology. 8th ed. John Wiley and Sons, London. 368 pp.

Zazharska, N., Boyko, O., BrygadYrenko, V. (2018): Influence of diet on the productivity and characteristics of goat milk. Indian J. Anim. Res., 52(5): 711 - 717. DOI: 10.18805/ijar.v0iOF.6826 